\title{
Effect of realistic simulation combined to theory on self- confidence and satisfaction of nursing professionals
}

\author{
Efeito da simulação realística combinada à teoria na autoconfiança e satisfação de profissionais de \\ enfermagem
}

\section{Efecto de la simulación realística combinada a la teoría en la autoconfianza y satisfacción de profesionales de enfermería}

Hanna Clara Teixeira Mesquita ${ }^{1}$ (D)
Breno de Sousa Santana ${ }^{2}$ (D)
Marcia Cristina da Silva Magro $^{2}$ (D)

1. Universidade de Brasília. Campus Ceilândia. Brasília, DF, Brasil.

2. Universidade de Brasília. Brasília, DF, Brasil.
Corresponding author:

Marcia Cristina da Silva Magro.

E-mail:marciamagro@unb.br.

Submitted on 09/06/2018.

Accepted on $11 / 20 / 2018$.

DOI: 10.1590/2177-9465-EAN-2018-0270

\begin{abstract}
Objective: To compare the effect of the use of the simulation strategy combined to theory with the simulation, per se, on the gain of self-confidence in nursing professionals during the management of the patient in cardiopulmonary arrest. Method: Quasiexperimental study with pre and post-tests, quantitative approach. Convenience sample composed of 53 professionals, divided into a control and experimental groups. The strategy was the intervention. A structured questionnaire and the satisfaction and self-confidence scale were used for data collection. Results with $\mathrm{p} \leq 0.05$ were considered significant. Results: Professionals were predominantly young $(33.2 \pm 6.5$ years $)$ and females $(84.9 \%)$. In the experimental group there was no significant difference $(p=0.1$ $v s \mathrm{p}=0.4$ ), but self-confidence increased significantly among the professionals in the experimental group in relation to the control $(p=0.007 v s p=0.06)$. Conclusion: The level of self-confidence of the nursing professionals for patient care in cardiopulmonary arrest improved significantly after using the combined simulation theory.
\end{abstract}

Keywords: Simulation; Nursing Assessment; Nurse Professionals; Personal Satisfaction; Confidence.

\section{Resumo}

Objetivo: Comparar o efeito do emprego da estratégia de simulação combinada à teoria com a simulação, per se, no ganho de autoconfiança em profissionais de enfermagem durante o manejo do paciente em parada cardiopulmonar. Método: Estudo quase experimental com pré e pós-testes, abordagem quantitativa. A amostra foi de conveniência e composta de 53 profissionais de enfermagem, divididos em grupo controle e experimental. A estratégia de simulação combinada à teoria foi a intervenção. Utilizou-se questionário estruturado e escala de satisfação e autoconfiança na aprendizagem para a coleta de dados. Resultados com $p \leq 0,05$ foram considerados significativos. Resultados: Os profissionais eram predominantemente jovens $(33,2 \pm$ 6,5 anos). No grupo experimental apesar da percepção relacionada a satisfação ter se mostrado superior, não houve diferença significativa ( $p=0,1$ vs $p=0,4)$. Mas a autoconfiança aumentou significativamente entre os profissionais do grupo experimental em relação ao controle ( $p=0,007$ vs $p=0,06$ ). Conclusão e implicações para a prática: $O$ nível de autoconfiança dos profissionais de enfermagem para atendimento ao paciente em parada cardiopulmonar melhorou significativamente após emprego da simulação combinada a teoria.

Palavras-chave: Simulação; Avaliação em Enfermagem; Profissionais de Enfermagem; Satisfação Pessoal; Confiança.

\section{Resumen}

Objetivo: Comparar el efecto del empleo de la estrategia de simulación combinada a la teoría con simulación, per se, en la obtención de autoconfianza en profesionales de enfermería durante el manejo del paciente en parada cardiopulmonar. Método: Estudio casi-experimental con pre/post-tests, abordaje cuantitativo. Muestra de conveniencia compuesta de 53 profesionales de enfermería, divididos en grupo control y experimental. La estrategia fue la intervención. Recolección de datos a través de cuestionario estructurado y escala de satisfacción y autoconfianza en aprendizaje. Considerados significativos resultados con $p \leq 0,05$. Resultados: Profesionales predominantemente jóvenes (33,2 $\pm 6,5$ años). En el grupo experimental no hubo diferencia significativa ( $p=0,1$ vs $p=0,4)$, pero la autoconfianza aumentó significativamente entre profesionales del grupo experimenta comparado al control $(p=0,007$ vs $p=0,06)$. Conclusión e implicaciones para la práctica: El nivel de autoconfianza de los profesionales de enfermería para atención al paciente en paro cardiopulmonar mejoró después de la simulación combinada a la teoría.

Palabras clave: Simulación; Evaluación en Enfermería; Personal de Enfermería; Satisfacción Personal; Confianza. 


\section{INTRODUCTION}

Simulation and simulated training are recognized as fundamental pedagogical strategies in the training of health professionals and are characterized by the impact in several dimensions, from satisfaction to the safety of the individual, the target of nursing care ${ }^{1}$.

Simulation is a process of cognitive and behavioral education, given the high levels of self-esteem and self-confidence they can provide, thus increasing the individual's ability to assimilate information and obtain gains in their learning process ${ }^{2}$.

It is well known that the health environment is increasingly complex and constantly changing. Therefore, nurses must work efficiently and collaboratively with their staff and avoid acting alone. It is through collaborative practice that health professionals of different backgrounds are encouraged to work together with patients and their families in order to improve and achieve the highest quality results related to the care process, reducing health costs and consequently achieving greater organizational progress ${ }^{3,4}$.

In recent years, simulation-based learning activities have been especially useful in improving professional performance. In particular, the simulation with professionals has been adopted to improve different competencies; in addition, it allows reproducing an experience that mimics a real situation, aiming to achieve transformative learning ${ }^{5}$.

The immersion of professionals in clinical settings allows familiarization with the patient care process, which favors cognitive development, self-confidence in decision-making, critical thinking, teamwork and psychomotor, affective and perceptive skills ${ }^{6}$.

The simulation has gained importance for the training and updating of health professionals, by allowing to reproduce clinical events in a safe environment, results in learning gains due to the possibility of the learner developing skills, critical thinking, decision making, teamwork and, especially, strengthening self-confidence ${ }^{7}$.

In the field of education, the training of professionals progressively favors the acquisition of new knowledge through the use of technologies and the development of quality indicators used in the work process that directly influence the care provi$\mathrm{ded}^{8}$. Thus, continued education becomes relevant when there is concern to ensure not only the quality of education services, but also to improve patient care ${ }^{9}$.

The realistic simulation is part of a teaching modality that provides from the practice of technical skills, as well as crisis management, leadership, teamwork, clinical reasoning in critical situations or that can cause harm to the real patient, being a powerful tool of learning ${ }^{10}$.

The restricted number of studies directed to the application of this modality in the interprofessional scenario for the development of competences and improvement of self-confidence motivated the proposal of this study, whose objective was to compare the effect of the use of the strategy of simulation combined with the theory to simulation, per se, in the gain of self-confidence in nursing professionals during the management of the patient in cardiopulmonary arrest.

\section{METHOD}

A quasi-experimental study with a quantitative approach performed in the simulation laboratory and consulting room of a teaching hospital considered a reference in the Federal District. The study population consisted of 119 professionals, 55 of the medical clinic, 40 of the critical patients unit and 24 of the intensive care unit. The sample was of convenience, and it consisted of 53 nursing professionals (nurses, technicians and nursing auxiliaries) due to the unavailability of the majority being absent from the sector of performance. Of this total, 26 professionals composed the experimental group and 27 the control group.

Professionals who were willing to take part in the study, who did not undertake cardiopulmonary resuscitation (CPR) course or training in the last two months, with professional practice time in the unit for at least two months, and participation in all stages of the study were eligible. Those who did not provide direct assistance to the patient and those on vacation or some form of labor leave were excluded.

For data collection, we applied (1) structured questionnaire of sociodemographic and professional characterization (identification, training time, sector and shift of professional performance) in the baseline period (pre-simulation) and the (2) Student Satisfaction and Self-Confidence in Learning Scale with questions adapted for professionals in cardiopulmonary arrest situation in the pre/initial and post-simulation period (three months after simulated practical activity). Cronbach's alpha of this scale is 0.86 for the satisfaction construct (06 items), 0.77 for the self-confidence construct with learning (07 items) and 0.84 for the general scale ${ }^{11}$. The scale is composed of 13 questions and two dimensions, with five possible answers: (1) strongly disagree with the statement, (2) disagree with the statement, (3) undecided - neither disagree nor agree with the statement, (4) agree with the statement and (5) strongly agree with the statement. As an educational intervention, the simulation strategy was adopted in both groups (control and experimental), with an increase in theoretical classes only in the latter. The validation of the simulated scenario regarding appearance, organization, consistency of objectives, availability of material and human resources, and realism was carried out by five teachers/experts.

The triggering strategy in order to sensitize the professionals to the participation was made effective by the researcher's visit to each of the professional's sector of performance. The accepted participation was recognized by the signing of the Term of Free and Informed Consent and the Term of Image and Voice Sound. Afterwards, they were taken to the office where they filled in the sociodemographic and professional data questionnaire and the satisfaction and self-confidence scale.

Sequentially, the professionals were grouped in two or three to begin the simulation practice in the laboratory where they developed the necessary activities to resolve the scene on cardiopulmonary arrest with duration of 15 minutes. In order to 
reproduce this scene, the simulator MetiMan of Civiam $₫$ was able to mimic real sounds and expressions, as well as consumables (utensils, syringe, needle, alcohol $70 \%$, medicines, gloves) and equipment, such as defibrillator and cardiopulmonary restraint cart. Afterwards, they participated in the debriefing, moment of reflection and discussion about the performance after the experience of the scenario, lasting 20 minutes. The measure of self-confidence in patient care in cardiopulmonary arrest was also performed at three months after simulated experience with all participants (control and experimental group) through the satisfaction and self-confidence scale.

The use of the theoretical class with multimedia occurred before the simulated practice differentiated the control group from the experimental one. Only the professionals of the experimental group participated, during the work shift, of the simulation, and also of this class with the theme: "Cardiopulmonary arrest by pulseless tachycardia", whose duration was 30 minutes, in an environment reserved within the own institution, obeying the criterion for the release of the chief professionals.

The collected data were submitted to the appropriate codification and entered in database, by means of the elaboration of a dictionary (code book) in spreadsheet of Microsoft Excel ${ }^{\circledR}$. Afterwards, they were submitted to the double-digit validation process and later exported to the Statistical Package for Social Science - SPSS $®$, version 23 , for statistical analysis.

All data were expressed as mean and standard deviation, median and $25^{\text {th }}$ and $75^{\text {th }}$ percentiles for quantitative variables and in absolute and relative frequencies for qualitative variables (descriptive statistics). As normality was not found, the non-parametric test, Mann-Whitney, was used for two independent samples. The paired comparison between the groups was performed by Wilcoxon's non-parametric test. The results with $p \leq 0.05$ were considered significant.

The study accomplished the ethical aspects of research involving human beings regulated by the National Health Council, through Resolution 466/2012 and was approved by the Research Ethics Committee of the Faculty of Health Sciences of the University of Brasília - FS / UnB, with CAEE no 64429617.6.0000.0030, opinion $\mathrm{n}^{\circ} 2.200 .558$.

\section{RESULTS}

In this study, the age of the 53 professionals included was $33.2 \pm 6.5$ years and the female gender predominated $(84.9 \%)$. Most of the professionals declared themselves to be nurse technician/assistant (67.9\%) and $32.1 \%$ as nurses working predominantly in the daytime period $(90.6 \%)$. It was homogeneous the distribution among professionals of the control and experimental group. The average time of performance in the exercised function was 29 months, although they worked in the institution at an estimated 32 months (Table 1).

Performance improvement was observed during the cardiopulmonary arrest event of the experimental group when compared to the control group, but without significant difference. In the first, the initial score of the professionals was $46.6 \pm 17$ and with the evolution reached $53.0 \pm 25$. In the second, this evolution went from $47.7 \pm 21$ to $54.3 \pm 27$ points. In this context, professionals from both groups showed improvement from the initial phase of the study to the final phase.

The satisfaction of professionals in relation to learning in both the experimental and control groups showed improvement from baseline to the condition after implementation of teaching strategies. Satisfaction with knowledge gain in the experimental group increased from $3.2 \pm 1.0$ to $3.5 \pm 0.8$ on the scale. In the control group this elevation was slightly more discrete from $3.8 \pm 0.8$ to $3.9 \pm 0.7$. In both situations without statistical relevance $(p=0.1$ vs $\mathrm{p}=0.4$ ), respectively.

Regarding self-confidence, there was a significant improvement in the professionals of the experimental group from the initial to the final phase $(p=0.007)$, different from the control group, although there was no statistical improvement $(p=0.06)$ (Table 2).

\section{DISCUSSION}

This study compared the effect of the use of the strategy of simulation combined to theory with the simulation, per se, on the gain of self-confidence in nursing professionals during the management of the patient in cardiopulmonary arrest. The results confirmed that the self-confidence of the professionals exposed to the combined simulation (experimental group) improved significantly over that with simulation alone. On the other hand, in both groups the level of satisfaction increased, although it was not significant. Increasing self-confidence and satisfaction with the simulation has a protective impact on the level of anxiety, as well as increases the confidence and self-efficacy of patient care. Surely, simulation experiments promote well-articulated learning outcomes, of theory with practice ${ }^{12,13}$. Scientific evidence highlighted the simulation as a strategy that involves learners from different perspectives, making them reflect and reformulate the practice, urging the thinking and doing together ${ }^{14}$.

The ability to detect quickly, accurately and reliably a patient's clinical decline and intervene adequately is one of the skills of nurses. However, the literature suggests delays in recognition, intervention and, sometimes, even absence of action, resulting in a negative impact on patient care. Different factors are suspected of causing delays and lack of recognition, including deficits in knowledge, communication and confidence in one's own assessment skills ${ }^{15,16}$.

Simulation-based education demonstrates improving nurses' confidence, knowledge and communication, especially when there is an emphasis of patients in clinical decline ${ }^{17-22}$. A similar finding was identified in the present study where professionals who experienced the strategy of simulation combined to theory had a significant increase in self-confidence in relation to the group that experienced only the simulation.

Currently the nurse has a generalist, humanistic, critical and reflexive training, essential characteristics that qualify him/her with a scientific and intellectual framework based on ethical and legal principles ${ }^{23}$. The training of specific skills is fundamental, but it is in the resolution of complete and complex scenarios, in a simulated 
Table 1. Sociodemographic and professional characterization of control and experimental groups. Brasília, 2018.

\begin{tabular}{|c|c|c|c|c|}
\hline Characteristics & & $\begin{array}{l}\text { Experimental Group } \\
n=26\end{array}$ & $\begin{array}{c}\text { Control Group } \\
n=27\end{array}$ & $\begin{array}{l}\text { Total } \\
n=53\end{array}$ \\
\hline Female gender & $n(\%)$ & $21(80.8 \%)$ & 24 (88.9\%) & 45 (84.9\%) \\
\hline Age (years) & Average $\pm \mathrm{DP}$ & $33.4 \pm 6.4$ & $33.1 \pm 6.8$ & $33.2 \pm 6.5$ \\
\hline Training time (years) & Median (25-75) & $8(5-10)$ & $7(5-11)$ & $7(5-10)$ \\
\hline \multicolumn{5}{|l|}{ Training area } \\
\hline $\begin{array}{l}\text { Urgency and Emer- } \\
\text { gency Nursing }\end{array}$ & $n(\%)$ & $0(0.0 \%)$ & $2(7.4 \%)$ & $2(3.8 \%)$ \\
\hline \multirow[t]{2}{*}{$\begin{array}{l}\text { Nursing in Intensive } \\
\text { Care }\end{array}$} & $n(\%)$ & $4(15.4 \%)$ & $3(11.1 \%)$ & $7(13.2 \%)$ \\
\hline & $n(\%)$ & 9 (34.6\%) & 8 (29.6\%) & 17 (32.1\%) \\
\hline
\end{tabular}

Postgraduatelato

sensu

\section{Occupation}

$\begin{array}{llccc}\text { Nurse } & \mathrm{n}(\%) & 9(34.6 \%) & 8(29.6 \%) & 17(32.1 \%) \\ \begin{array}{l}\text { Nursing Technician/ } \\ \text { assistant }\end{array} & \mathrm{n}(\%) & 17(65.4 \%) & 19(70.4 \%) & 36(67.9 \%)\end{array}$

\section{Sector of Work}

$\begin{array}{lcccc}\text { Critical Care Unit } & \mathrm{n}(\%) & 17(65.4 \%) & 23(85.2 \%) & 40(75.4 \%) \\ \text { Intensive Care Unit } & \mathrm{n}(\%) & 7(26.9 \%) & 4(14.8 \%) & 11(20.8 \%) \\ \text { Medical Clinic } & \mathrm{n}(\%) & 2(7.7 \%) & 0(0.0 \%) & 2(3.8 \%)\end{array}$

Shift

\begin{tabular}{lcccc} 
Daytime & $\mathrm{n}(\%)$ & $25(96.2 \%)$ & $23(85.2 \%)$ & $48(90.6 \%)$ \\
\hline $\begin{array}{l}\text { Nocturnal } \\
\begin{array}{l}\text { Time performing } \\
\text { (months) }\end{array}\end{array}$ & $\mathrm{n}(\%)$ & $1(3.8 \%)$ & $4(14.8 \%)$ & $5(9.4 \%)$ \\
\hline $\begin{array}{l}\text { Time at institution } \\
\text { (months) }\end{array}$ & Average \pm DP & $22 \pm 12$ & $37 \pm 50$ & $29 \pm 37$ \\
\hline
\end{tabular}

Source: Authors.

Table 2. Comparison of self-confidence in learning between groups in the initial evaluation (pre-test) and in knowledge retention stages. Brasília, 2018.

\begin{tabular}{|c|c|c|c|}
\hline \multirow{3}{*}{ Groups } & \multicolumn{2}{|c|}{ Study stages } & \multirow{3}{*}{$\begin{array}{l}\text { Value } \\
\text { p }\end{array}$} \\
\hline & Pre-simulation & $\begin{array}{l}\text { Post-simulation } \\
\text { / Retention }\end{array}$ & \\
\hline & Median (25-75) & Median (25-75) & \\
\hline $\begin{array}{l}\text { Experimental } \\
(n=24)\end{array}$ & $3.4(2,8-3,8)$ & $3.8(3,5-4,1)$ & 0.007 \\
\hline $\begin{array}{l}\text { Control } \\
(n=27)\end{array}$ & $3.8(3,4-4,0)$ & $3.9(3,5-4,3)$ & 0.06 \\
\hline
\end{tabular}

context, that nurses consolidate their knowledge and develop the capacity for critical judgment and decision making, as well as in the development of competencies, and in the different technical, attitudinal and ethical dimensions ${ }^{1}$.

Exposure to certain scenarios, such as cardiopulmonary arrest, is not common during graduation or even in the professional sector. However, it is necessary to be able to deal effectively with this situation. The simulated training allows this opportunity without risk of harm to the patient, and the acquired learning allows experiencing and solving with greater confidence critical situations.

Realistic simulation is currently a propulsive tool in the health scenario in the country, being suggested as a practice applied in favor of the training of nursing undergraduates and 
professionals, benefiting the process of teaching and learning in the permanent formation ${ }^{8}$. The insertion of simulation as a training strategy, continuous education and evaluation of professionals is relevant in the health scenario, as identified in the present study.

The simulation is influential to the development of cognitive, psychomotor, and attitudinal knowledge, providing real learning, where real-life situations can be transformed into experiences. Given its relevance, it can contribute to improve the criticism, cognitive ability and the use of technology, making it possible to transform theoretical knowledge into practice in an interactive way $^{24}$, especially when associated with the theoretical approach, as adopted in this study by reinforcing the transmission of content to the professionals in a practical opportunity stimulating the analysis of a certain situation in which the professional can review their errors and seek to avoid them in future situations.

The teaching and learning process should aim to overcome repetitive and monotonous knowledge, as well as include learning methodologies based on dialogue, with a view to instigating collective and reflexive discussion ${ }^{25}$.

Self-confidence is considered an indicator of sufficient proactivity to intervene in emergency situations, when every second counts. The health professional should feel confident about the ability to act properly, otherwise delays may occur in the assistance, elevation of the level of anxiety and number of errors ${ }^{26}$. In this study, it was possible to notice that the gain of self-confidence was associated with the simulation combined with the theoretical approach $(p=0.007)$.

In this way, the importance of realistic simulation as a strategy applicable to health education actions, from undergraduate to continuing training of health professionals, was perceived ${ }^{27}$. It is noted that both the isolated simulation and the simulation combined with theoretical approach, has its effectiveness, modifying behaviors, increasing self-confidence, developing specific skills, favoring patient safety and its satisfaction.

As limitations, this study consisted of a small sample size, without randomization when considering selection by convenience. On the other hand, benefits such as the achievement of best practices in the caring process deserve to be highlighted and represent the way to reach the quality of care.

\section{CONCLUSION AND IMPLICATIONS FOR PRACTICE}

The level of self-confidence of the nursing professionals for patient care in cardiopulmonary arrest improved significantly after using the simulation combined to theory in comparison to the exclusive use of simulation. In fact, practitioners were more satisfied with the gain of knowledge acquired through the combined experience.

Further studies are needed to verify the need to associate the theoretical approach with the simulated practice as a marker of improvement of the utilization rate among nursing professionals during the promotion of critical patient care.

\section{REFERENCES}

1. Martins JCA. Aprendizagem e desenvolvimento em contexto de prática simulada. Rev Enferm Ref [Internet]. 2017; Mar;12:155-62. Available from: http://www.scielo.mec.pt/scielo.php?script=sci_ arttext\&pid=S0874-02832017000100016\&Ing=pt. http://dx.doi. org/10.12707/RIV16074

2. Miranda FBG, Mazzo A, Pereira Junior GA. Uso da simulação de alta fidelidade no preparo de enfermeiros para o atendimento de urgências e emergências: revisão da literatura. Sci Med (Porto Alegre) [Internet]. 2018 Jan 26;28(1):28675. Available from: http://revistaseletronicas. pucrs.br/scientiamedica/ojs/index.php/scientiamedica/article/ view/28675

3. Reeves S, Perrier L, Goldman J, Freeth D, Zwarenstein M. Interprofessional education: effects on professional practice and healthcare outcomes (update). Cochrane Database Syst Rev. 2013 Mar 28;(3):CD002213. Available from: https://www.ncbi.nlm.nih.gov/ pubmed/23543515

4. Reeves S, Fletcher S, Barr H, Birch I, Boet S, Davies N, et al. A BEME systematic review of the effects of interprofessional education: BEME Guide No. 39. Med Teach [Internet]. 2016 Jul 2;38(7):656-68. Available from: https://www.tandfonline.com/doi/full/10.3109/014215 9X.2016.1173663

5. Failla KR, Macauley K. Interprofessional Simulation: A Concept Analysis. Clin Simul Nurs [Internet]. 2014 Nov;10(11):574-80. Available from: http://dx.doi.org/10.1016/j.ecns.2014.07.006

6. Bortolato-Major C. O ensino baseado em simulação e o desenvolvimento de competências clínicas de estudantes de enfermagem [tese]. [Internet]. Curitiba: Universidade Federal do Paraná; 2017. Available from: https://acervodigital.ufpr.br/bitstream/handle/1884/53429/R-TCARINABORTOLATO-MAJOR.pdf? sequence=1\&isAllowed=y

7. Negri EC, Mazzo A, Martins JCA, Pereira Junior GA, Almeida RGS, Pedersoli CE. Clinical simulation with dramatization: gains perceived by students and health professionals. Rev Lat Am Enferm [Internet] 2017 Aug;25:e2916. Available from: http://www.scielo.br/scielo. php?script=sci_arttext\&pid=S0104-11692017000100604

8. Miranda RPR, Motta AL, Chaves ECL, Resck ZMR, lunes DH. A aplicabilidade do uso de Simulação Realística na Formação Permanente do Profissional de Enfermagem. Rev Interdiscip Est Saúde [Internet]. 2016;4(2):54-62. Available from: https://periodicos.uniarp.edu.br/ries/ article/view/713.2916

9. Govranos M, Newton JM. Exploring ward nurses' perceptions of continuing education in the clinical setting. Nurse Educ Today [Internet]. 2014 Apr;34(4):655-60. Available from: https://ac.els-cdn. com/S0260691713002414/1-s2.0-S0260691713002414-main.pdf? tid=98f74983-e469-400e-a193-6de17692b210\&acdnat $=1535392720$ _86987a00da36619283cec08effaa9e94

10. Souza CDF, Antonelli BA, Oliveira DJ. Metodologias ativas de ensino aprendizagem na formação de profissionais de saúde. Rev Univ Val do Rio Verde [Internet]. 2016;14(2):659-77. Available from: http://periodicos. unincor.br/index.php/revistaunincor/article/view/3135

11. Almeida RGS, Mazzo A, Martins JCA, Baptista RCN, Girão FB, Mendes IAC. Validação para a língua portuguesa da escala Student Satisfaction and Self-Confidence in Learning. Rev Lat Am Enferm [Internet]. 2015 Nov/Dec;23(6):1007-13. Available from: http://www.scielo.br/scielo. php?script=sci_arttext\&pid=S0104-11692015000601007\&Ing=en . http://dx.doi.org/10.1590/0104-1169.0472.2643

12. Baptista RCN, Paiva LAR, Gonçalves RFL, Oliveira LMN, Pereira MFCR, Martins JCA. Satisfaction and gains perceived by nursing students with medium and high-fidelity simulation: A randomized controlled trial. Nurse Educ Today [Internet]. 2016 Nov;46:127-32. Available from: http://dx.doi. org/10.1016/j.nedt.2016.08.027

13. Tiwari SR, Nafees L, Krishnan O. Simulation as a pedagogical tool: Measurement of impact on perceived effective learning. Int $\mathrm{J}$ Manag Educ [Internet]. 2014 Nov;12(3):260-70. Available from: https://ac.elscdn.com/S147281171400041X/1-s2.0-S147281171400041X-main. pdf? tid=b15e8532-3a3b-4958-a621-2476f3000531\&acdnat $=15402$ 56154_354532e5758cfe9baed9e816d437c04b 
14. Jeffries PR. The NLN Jeffries Simulation Theory. National League for Nursing (NLN). New York: Wolters Kluwer; 2015.

15. Hallin K, Bäckström $B$, Häggström $M$, Kristiansen L. Highfidelity simulation: Assessment of student nurses' team achievements of clinical judgment. Nurse Educ Pract [Internet] 2016 Jul;19:12-8. Available from: https://ac.els-cdn.com/ S1471595316300129/1-s2.0-S1471595316300129-main.pdf? tid=e85119ba-41bf-4c72-b777-e473a84edf0e\&acdnat=1540261288 f5b7559cec3e9578e2cbb4473a951e44

16. O'Leary J, Nash R, Lewis P. Standard instruction versus simulation: Educating registered nurses in the early recognition of patient deterioration in paediatric critical care. Nurse Educ Today [Internet] 2016 Jan;36:287-92. Available from: http://dx.doi.org/10.1016/j. nedt.2015.07.021

17. Bell-Gordon C, Gigliotti E, Mitchell K. An evidence-based practice project for recognition of clinical deterioration: Utilization of simulationbased education. J Nurs Educ Pract [Internet]. 2014;4(6):69-76. Available from: http://www.sciedu.ca/journal/index.php/jnep/article/ view/4176

18. Boling B, Hardin-Pierce $M$. The effect of high-fidelity simulation on knowledge and confidence in critical care training: An integrative review. Nurse Educ Pract [Internet]. 2016 Jan;16(1):287-93. Available from: http://dx.doi.org/10.1016/j.nepr.2015.10.004

19. Bultas MW, Hassler M. Ercole PM, Rea G. Effectiveness of high-fidelity simulation for pediatric staff nurse education. Pediatr Nurs [Internet]. 2014 Jan/Feb;40(1):27-32. Available from: https://www.ncbi.nlm.nih. gov/pubmed/24757918

20. Figueroa MI, Sepanski R, Goldberg SP, Shah S. Improving teamwork, confidence, and collaboration among members of a pediatric cardiovascular intensive care unit multidisciplinary team using simulation-based team training. Pediatr Cardiol [Internet]. 2013 Mar;34(3):612-9. Available from: https://www.ncbi.nlm.nih.gov/ pubmed/22972517
21. Hart PL, Brannan JD, Long JM, Maguire MBR, Brooks BK, Robley LR. Effectiveness of a structured curriculum focused on recognition and response to acute patient deterioration in an undergraduate BSN program. Nurse Educ Pract [Internet]. 2014 Jan;14(1):30-6. Available from: http://dx.doi.org/10.1016/j.nepr.2013.06.010

22. Hommes T. Implementation of simulation to improve staff nurse education. J Nurses Prof Dev [Internet]. 2014 Mar/Apr;30(2):66-9. Available from: https://www.ncbi.nlm.nih.gov/pubmed/24658037

23. Rodrigues CCFM, Carvalho DPSRP, Salvador PTCO, Medeiros SM, Menezes RMP, Ferreira Júnior MA, et al. Ensino inovador de enfermagem a partir da perspectiva das epistemologias do Sul. Esc Anna Nery [Internet]. 2016 Apr/Jun;20(2):384-9. Available from: http://www.scielo.br/scielo.php?script=sci_arttext\&pid=S1414$81452016000200384 \&$ Ing=en. http://dx.doi.org/10.5935/14148145.20160053

24. Çelik Y, Ceylantekin Y, Kiliç I. The evaluation of simulation market in nursing education and the determination of learning style of students. Int J Health Sci (Qassim) [Internet]. 2017 Jan/Mar;11(1):1-6. Available from: https://www.ncbi.nlm.nih.gov/pubmed/28293150

25. Jacondino MB, Silveira DN, Martins CL, Coimbra VCC. Processo de ensino-aprendizagem do estudante de enfermagem e os estilos de aprendizagem. Rev Estilos Aprendiz [Internet]. 2015;8(15):31-50. Available from: http://learningstyles.uvu.edu/index.php/jls/article/ viewFile/222/184

26. Ferreira RPN, Guedes HMG, Oliveira DWD, Miranda JL. Simulação realística como método de ensino no aprendizado de estudantes da área da saúde. Rev Enferm Centro Oeste Min [Internet]. 2018;8:e2508. Available from: http://dx.doi.org/10.19175/recom.v8i0.2508\%09\%0A

27. Ferreira C, Carvalho JM, Carvalho FLQ. Impacto da metodologia de simulação realística, enquanto tecnologia aplicada a educação nos cursos de saúde. II STAES - Semin Tecnol Apl Educ Saúde [Internet]. 2015;32-40. Available from: http://www.revistas.uneb.br/index.php/ staes/article/view/1617 